\title{
Editors' Introduction: JBS 53.3 (July 2014)
}

\section{Brian Cowan Elizabeth Elbourne}

British history is, fortunately, no longer so devoted as it once was to the lives of dead white men. The fact that the current issue of the Journal of British Studies has such a rich focus on biography, including particular attention to the lives of men, should certainly not be read as indicative of any desire to turn back the clock. Nonetheless, it seems to us that there has been a recent revival of interest in biography. The current issue reflects this trend. The issue provides an opportunity to think about the uses of biography in a rapidly changing scholarly environment. How might historians approach the individual life as a microcosm of larger themes? How do we write collective biographies? How should we think about the biographies of men in particular in the context of their wider communities and gendered environments?

Prosopography, or the practice of collective biography, has been a prominent aspect of British historical study since the heyday of Sir Lewis Namier and the efflorescence of Namierite histories. This issue opens with a fresh new approach to prosopography in medieval studies. Kathleen Kennedy's "Prosopography of the Book and the Politics of Legal Language in Late Medieval England" merges book history with prosopography to illuminate the social and political significance of the recording and translation of late medieval English parliamentary statutes. Returning to the linguistic pluralism of late medieval England addressed by Gwilym Dodd previously in this journal, Kennedy studies translations of late medieval English parliamentary statutes from their original Latin or law French into the English vernacular. ${ }^{1}$ Because such translations were not linguistically necessary, as their owners and readers would have been able to read the statutes in their original language, Kennedy argues that they can best be understood through a methodology she calls a "prosopography of the book." This method, she states, "must take into account the physical document of the book and make it speak" (p. 568) but must also attend to the people (and their aggregate characteristics as discerned through prosopographical study) who made, purchased, and read the books that historians now use as source materials. Through this study, Kennedy finds "tantalizing hints of popular resistance" (p. 584) to the early Tudor monarchy in her translations.

By contrast, resistance was abhorrent to the highly influential seventeenth-century archbishop and theologian James Ussher, whose political thought Ian William Seymour Campbell analyzes in his "Calvinist Absolutism: Archbishop James Ussher and Royal Power.” In a previous article for this journal, Michael Winship illuminated the ways in which Calvinist theology could be compatible with republican

\footnotetext{
${ }^{1}$ Gwilym Dodd, "Trilingualism in the Medieval English Bureaucracy: the Use-and Disuse-of Languages in the Fifteenth Century Privy Seal Office," Journal of British Studies 51, no. 2 (2012): 253-83.
} 
politics and a resolute resistance theory in his study of Algernon Sidney's "Calvinist republicanism.” Seymour Campbell demonstrates here that Calvinism was equally reconcilable with a political theory of royal absolutism. ${ }^{2}$ Whereas Calvinist theology has often been associated with the development of theories of resistance, so much so that historians have spoken of a Calvinist theory of revolution, Seymour Campbell demonstrates that Calvinism could be equally compatible with a thoroughgoing repudiation of resistance theory. Seventeenth-century theology was intensely political, but a theological perspective as diverse and influential as Calvin's was labile enough to accommodate both royal absolutists and republicans. A focus on one theologian's attempt to reconcile Calvin's kingdom of God with the secular authority of the Stuart monarchy highlights the malleability of Calvinist theology under the pressures of seventeenth-century political divisiveness.

\section{FORUM: RADICAL LIVES}

In a forum on "radical lives" that comprises the middle section of this issue, biography is used to illuminate the history of British radicalism in the turbulent "age of revolutions" in the late eighteenth and early nineteenth centuries. Each of the articles in the forum uses a study of the life of one particular reformer or social critic as a case study to shed light on broader aspects of radical politics. Amanda Goodrich studies the Caribbean-born reformer Henry Redhead Yorke; Gregory Claeys explores the ideas of the utopian philosopher and eccentric adventurer "Walking" John Stewart; and Jonathan Wright focuses on the Irish-born parliamentary journalist and provocateur Peter Finnerty.

In her article "Radical 'Citizens of the World,' 1790-95: The Early Career of Henry Redhead Yorke," Amanda Goodrich traces the transnational life of Henry Redhead Yorke. Yorke should be familiar to Journal of British Studies readers as the subject of a recent article by Amnon Yuval. ${ }^{3}$ Moving beyond domestic history and following people though space is a very helpful way of bringing to light the international linkages of British radicalism. Yorke was the son of a white slave owner and an enslaved black woman who was sent to England from the West Indies for education. Goodrich argues that this insider-outsider status shaped Yorke's career. While Yorke began his public life as an advocate of slavery, this persona was quickly followed by several reincarnations and political repositionings with regard to the great debates of the day. After recanting his support for slavery, Yorke refashioned himself as a compelling radical orator and left Britain for a stint in France as a friend of the revolution. But he ended his vicissitudinous political journey as a conservative commentator, married to the daughter of his former gaoler. Goodrich suggests that Yorke saw himself, like many others, as a citizen of the world, as he tried to escape the chains of place. He also, however, was more vulnerable to political pressure than many of his fellow radicals with British roots-a fact that helps to explain his twisting career. In this case, biography shows the value of a transnational lens.

\footnotetext{
${ }^{2}$ Michael Winship, "Algernon Sidney's Calvinist Republicanism," Journal of British Studies 49, no. 4 (October 2010): 753-73.

${ }^{3}$ Amnon Yuval, "Between Heroism and Acquittal: Henry Redhead Yorke and the Inherent Instability of Political Trials during the 1790s," Journal of British Studies 50, no. 3 (July 2011): 612-38.
} 
Gregory Claeys details the colorful life of the eccentric utopian philosopher John Stewart, known among other things for his daily five-hour walking regime, who sought to introduce Eastern religious ideas to England and espoused free love avant la lettre. In "The Only Man of Nature That Ever Appeared in the World": 'Walking' John Stewart and the Trajectories of Social Radicalism, 1790-1822," Claeys argues that Stewart, who was well known in radical circles, was part of an important but underestimated movement of social radicalism that coexisted with the better-studied political radicalism of the 1790s and early 1800s. Stewart is also significant, Claeys claims, because his thought represents "a crucial transitional phase between the more utopian republicanism of the 1790s and the communitarianism of the Welsh-born cotton-spinner turned philanthropist Robert Owen, from which British socialism would emerge between 1820 and 1850" (p. 638). A close reading of Stewart's life and works suggests a new trajectory for the history of ideas. And, once again, tracing the trajectory of an individual through space reveals the movement of ideas and influences as well as people.

In "An Anglo-Irish Radical in the Late Georgian Metropolis: Peter Finnerty and the Politics of Contempt," Jonathan Wright examines the life and career of Peter Finnerty, showing the importance of Irish networks and political ideas to early nineteenth-century political radicalism. A radical journalist and parliamentary reporter, who throughout his life was an implacable and effective opponent of Lord Castlereagh, Finnerty was shaped by his early career as a radical printer in Ireland. Early arrest by British forces doubtless confirmed him in his political views. As Wright illustrates, Finnerty was part of an important wider Irish radical diaspora in London. A close study of Finnerty's career suggests how closely Irish and English issues were interwoven in the age of transnational revolutions. It also enables Wright to present a microstudy of what he convincingly terms the "politics of contempt" that both characterized Finnerty's career and played such an important role in late Georgian radicalism.

Following the forum, the issue concludes with Erik Linstrum's article on James Strachey's translations of the works of Sigmund Freud, Sean O'Connell's study of the life and afterlife of the Irish loyalist killer Buck Alec Robinson, and Radhika Natarajan's examination of the Commonwealth Arts Festival of 1965. At the heart of all these articles are issues of identity and belonging, whether individual or collective.

In "The Making of a Translator: James Strachey and the Origins of British Psychoanalysis," Eric Linstrum argues for the value of understanding the individual life and concerns of James Strachey, an eminent early translator of Freud into English, as a route to better understanding his translation. Strachey had a very significant influence on how readers in English understood Freud, particularly through his use of neologisms and his painstaking efforts to create a "scientific" and "rational" text. Among other things, Linstrum suggests that Strachey's own fear of postwar chaos and the breakdown of social order help explain the controlled rigidity of his translation. In keeping with recent work in diverse fields, Linstrum pays attention to the act of translation and to the various contexts in which translation was produced, removing the illusion of transparency and forcing us to think about cultural mediation and perhaps about translation itself as a form of authorship. 
Sean O'Connell studies the life of an infamous Belfast "hard man" in his "Violence and Social Memory in Twentieth-Century Belfast: Stories of Buck Alec Robinson." O'Connell is interested not only in the masculinity enacted by "Buck" Robinson during his lifetime, and the importance of such "hard men" to urban politics and community life in general, but also in the social memory of Robinson. How has Robinson been remembered and commemorated? And how does the memory of a single individual encapsulate larger trends? O'Connell argues that Robinson is often remembered in benign terms that belie his actual role as a loyalist enforcer or his embrace by loyalist elites in a deeply fractured society. In the process of examining Robinson's life, O'Connell engages with Norbert Elias's concept of the "civilizing process," using his microstudy to critique any teleological approach to the decline of violence in modern society. Not least, the study illuminates how violence worked in practice, at a granular level, and how those involved thought about violence. Violence was a crucial part of how Robinson defined and experienced being a man, and his life sheds light on a particular vision of masculinity. The study raises the issue of how to include memory and commemoration in the study of a life, complicated not least by the fact that O'Connell draws on oral sources that themselves call on memory.

Finally, we turn to an essay on a very different topic: Radhika Natarajan's "Performing Multiculturalism: The Commonwealth Arts Festival of 1965." If this essay is only tangentially related to the topic of biography, it does engage extensively with the enactment of collective identity. Natarajan looks at what the cultural politics of the 1965 Commonwealth Arts Festival can tell us about the self-positioning of Britain and of a variety of "Commonwealth" countries in the era of decolonization. Natarajan contextualizes the concept of multiculturalism by exploring its imperial roots: diverse new nations needed to produce legible accounts of national identity in order to interact on the Commonwealth stage. This was true even for countries such as Nigeria and Canada that had difficulty producing a single national narrative and fell back themselves on the idea of a multicultural identity. In this sense, the imagined nation was a political and cultural actor, as nations presented themselves on a British stage, enacting their own collective biographies. By reflecting on the role of cultural politics in the history of postwar international relations, Natarajan opens up new ways of thinking about the early history of the Commonwealth.

The next issue of the Journal of British Studies will open with a forum on new approaches to the English Revolution. The four articles in this forum will highlight diverse ways of studying the mid-seventeenth-century crisis, including contributions from the history of political thought, legal history, and social history. The remaining articles in the issue cover the eighteenth through the twentieth centuries. One addresses Britain's relationship to the Spanish empire in the 1760s and disputes over search warrants and freedom of speech in imperial debate, while another article explores early nineteenth-century attitudes toward adoption through the life and contested image of William Austin, Queen Caroline's adopted son. A further article sheds new light on the Irish Easter Rebellion of 1916 and the relationship between its socialist roots and military tactics. The issue concludes by continuing the theme of biography through a collective biography of six working-class intellectuals who played key roles in Britain's mid- to late twentieth-century cultural life and together illustrate the concerns of a particular generation of "scholarship boys." 